\title{
COMPARATIVE ANALYSIS OF HONEY CONSUMPTION IN ROMANIA, ITALY AND SERBIA
}

\author{
Svetlana D. Ignjatijević ${ }^{* 1}$, Radivoj V. Prodanović ${ }^{2}$, Jelena Z. Bošković ${ }^{2}$, Nikola M. Puvača ${ }^{2}$, \\ Mirela J. Tomaš Simin ${ }^{3}$, Tatjana A. Peulić ${ }^{4}$, Olivera M. Đuragić ${ }^{4}$ \\ ${ }^{1}$ University Business Academy, Faculty of Economics and Engineering Management, Department of \\ Business and International Economics, 21000 Novi Sad, Cvećarska 2, Serbia \\ ${ }^{2}$ University Business Academy, Faculty of Economics and Engineering Management, Department of \\ Engineering Management in Biotechnology, 21000 Novi Sad, Cvećarska 2, Serbia \\ ${ }^{3}$ University of Novi Sad, Faculty of Agriculture, Department of Economics in Agriculture and Rural \\ Sociology, 21000 Novi Sad, Trg Dositeja Obradovića 8, Serbia \\ ${ }^{4}$ University of Novi Sad, Scientific Institute of Food Technology, 21000 Novi Sad, \\ Bulevar cara Lazara 1, Serbia
}

*Corresponding author:

Phone: +381606442233

E-mail address: ceca@fimek.edu.rs

\begin{abstract}
Honey consumption is influenced by many factors such as health benefits, product characteristics, or demographic and sociological characteristics. The aim of the research was to identify factors that influence the volume of honey consumption, consumers' purchasing intentions, as well as to define the consumer profile in Romania, Italy, and Serbia. The research was conducted in the period from 2014 to 2016 through a questionnaire. The statistical significance of the difference in the consumption of honey in Serbia (Province of Vojvodina), Italy (the Province of Lombardy, which geographically resembles Vojvodina) and Romania was investigated. For the selection of a representative sample, random selection method was used, and the obtained data were processed using the SPSS program. The strongest motives for honey consumption were the satisfaction related to the taste honey provides and the perception that it is a healthy food. The chi-squared test showed that there was a significant difference among the countries in terms of demographic and economic characteristics of consumers, trends, and tendencies in the consumption of honey and sociological characteristics of consumers.
\end{abstract}

Key words: honey consumption, consumer profile, health aspect

\section{INTRODUCTION}

Honey is becoming an increasingly popular product among consumers. It plays an important role in the field of medicine, pharmacology, food industry, cookery, etc. Honey is used for medical as well as beauty purposes (Yeow et al., 2013). Honey is considered a tasty product and a product beneficial to the health of most respondents (Pocol and Bolboacă, 2013; Jakšić et al., 2018). Awareness of the connection between food and nutrition with health has become one of the important aspects for consumers, which influences their purchase decisions (Magnusson et al., 2001; Bogoeva, 2018). Honey is a product with very rich symbolism and it is present in all cultures, but its consumption is a variable category. It is, therefore, necessary to identify the wishes and expectations of consumers, which must correspond to the perception they have about this product (Haderbache and Mohammed, 2015). Consumer education to adopt a healthy lifestyle can significantly contribute to an increase in honey consumption (Pocol and Bolboacă, 2013). Ignja- 
tijević et al. (2015) analyzed the level of honey production in Serbia and indicated that in the period from 2001 to 2013, it amounted to the average of 4173 tons. The demand was satisfied by domestic production, and the remaining quantities were intended for export. In the analyzed period, there was an increase in exports, which points to a trend of growing demand in the international market. The health benefits of honey consumption are one of the factors that are expected to increase consumption (Plavša et al., 2011). The research showed that the average annual consumption of honey per capita in Poland is $0.60-0.62 \mathrm{~kg}$ per person which is significantly higher than the average consumption in Romania (Pocol, 2012), amounting to barely $0.37 \mathrm{~kg}$, although Romania is one of the largest producers in the EU. The EU-25 average is $0.7 \mathrm{~kg}$ per person. The annual consumption of honey among surveyed households is $1.32 \mathrm{~kg}$ per person. Only $20.6 \%$ of respondents reported that they consumed honey every day, while almost $39 \%$ of respondents said they consumed honey only occasionally. A study conducted in France in 2000 by AFSSA (Volatier, 2000) showed that the average consumption of honey in France was $0.438 \mathrm{~kg}$ per capita per year (the total population), or $2.556 \mathrm{~kg}$ per capita (consumers). The total estimated annual consumption of honey in Saudi Arabia per capita ranges from $0.46 \mathrm{~kg}$ to $11.3 \mathrm{~kg}$, with amounts to $4.5 \mathrm{~kg}$ on average. This average consumption of honey per capita is relatively high compared to other countries. The average annual income of Saudi Arabia (around \$27000 per household) is high and one of the reasons for higher consumption of honey, in addition to their customs and culture. The average price of honey in Saudi Arabia is $\$ 73$ per $\mathrm{kg}$ which is 10 times higher than the average price of honey in the US and EU.

The consumption of honey is influenced by various factors, whether in terms of product characteristics or demographic and sociological characteristics. Consumption, or purchase of honey, is determined by different factors, of which quality is in the first place. Other factors that influence purchase decisions are important: health benefits, brand reputation, packing, and price. However, it should be also noted that color, brand, design, and image play an important role and influence the behavior of consumers and their purchasing intentions. With the increasing size of the market, consumers' demands are increasing as well, so honey producers have to search for new approaches and to learn to understand the "need to increase consumer satisfaction with products in order to build consumer loyalty" (Yeow et al., 2013). The suitability of honey for use is very important and points to the potential of purchasing and consumption, but also to possible barriers to purchasing (Stolzenbach et al., 2013). According to Pocol and Bolboacă (2013), consumers prefer honey from local, traditional systems, because they give them more confidence (Pocol and Bolboacă, 2013). Education, occupation, and age are factors that significantly affect consumer preferences regarding the value of honey in the NorthWest region of Romania. Although Romania is one of the leading EU honey producers, it sounds paradoxical that there is no consumption culture for this product, so honey consumption is lower than in other European countries (Pocol and Bolboacă, 2013). Honey is mostly consumed by those with higher education, or by those with high professional status, as well as by the category of a population between 26 and 50 years of age. Consumers prefer honey from local production systems. Rare types of honey are actually very tasty and well-accepted among consumers, but they are not so popular and consequently less represented in consumption (Pocol, 2012). Murphy et al. (2000), conducted a study of Irish consumers' preferences for their honey. The results showed that the most important factors for consumers are the price and texture of honey, then the packing, the name of the manufacturer and the color of honey.

There is a trend of growing honey consumption in Romania, as well as a reduction in the number of people who never consume it. Most of the respondents $(88 \%)$ still consider the honey to be good for their health. Price can be considered as a limiting factor for the purchase of ho- 
ney since monthly income in Romania is in most cases below the EU average (Pocol and Bolboacă, 2013). Elderly people, lowlevel-educated people and the unemployed think honey is an expensive or luxurious product.

The study conducted in Romania by Arvanitoyannis and Krystallis (2006), suggests that more than $70 \%$ of respondents buy at least $500 \mathrm{~g}$ of honey within a threemonth period. They mostly buy acacia honey and lime honey directly from the manufacturer or at the market places. Key motives are the following: medical benefits of honey consumption; dietary quality of honey; an ethical character of honey; and fitting of honey into health food consumption lifestyle. The most important factors for the consumers are the purchase of prices and the quality of honey, and very little attention is paid to the label, warranties, brand name and country-of-origin sign (Arvanitoyannis and Krystallis, 2006).

Ćirić et al. (2015) finds that the consumers in Serbia, who buy the largest quantities of honey, buy from $0.33-1 \mathrm{~kg}$ of honey on monthly basis. The profile of honey consumers in Serbia is persons age 20 - 40, with high education, from three-member and four-member households, with revenues between 501-1000 euros (39.4\%) and 1001-2000 euros (36.4\%). Honey consumers are people who take care of their nutrition partly or completely, who regularly or occasionally exercise, or engage in some kind of physical activity, or people who lead a healthy lifestyle. The strongest motives for the purchase of honey are its taste and the perception of honey as a healthy food. Honey is bought all year round, and the only statistically significant reference group that has an impact on purchasing decisions is the family, while most respondents make a decision on their own.

The aim of the study was to identify factors that influence consumers' intention to buy honey, as well as to define the profile of honey consumers in Romania, Italy and Serbia. For this purpose, the study examined consumers' perceptions, their purchasing intentions and the extent of honey consumption. The study of honey consumption provides useful information that can be used to improve the marketing strategy. The results will enable professionals to better understand the current situation in terms of consumer behavior that influences the consumption of honey, identifying key issues and possible solutions.

\section{MATERIALS AND METHODS}

\section{Location of experimental research}

Based on the study by Ćirić et al. (2015) and Pocol and Bolboacă (2013), we have conducted a study of honey consumption in Serbia, Italy and Romania. The survey was conducted in the territory of Italy in several locations in the province of Lombardy, from October 2015 to March 2016. The survey covered 610 consumers of honey and 169 respondents who do not consume honey. In Romania, the survey was carried out throughout the country from December 2015 to March 2016, on a sample of 553 consumers of honey and 27 non-consumers. The survey of honey consumption in Serbia (the Province of Vojvodina), was conducted in the period from the end of 2014 to May 2015. In Vojvodina, the study covered 472 consumers of honey and 28 non-consumers. The authors decided to research the existence of a statistical significance in the difference in honey consumption in Serbia (the Province of Vojvodina) and Italy (the Province of Lombardy, which geographically resembles Vojvodina) and Romania. The random sample method was used to select a representative sample.

\section{Questionnaire related to sociological characteristics of consumers}

A survey questionnaire was compiled with three sets of questions. The first group included economic, demographic and sociological characteristics of consumers. The second group of questions included 6 questions related to trends and preferences in honey consumption. The third group of questions consisted of 5 questions related to sociological characteristics of consumers, i.e. to the leading of a healthy lifestyle of honey consumers.

\section{Statistical analyses}

The survey was created using the Google Forms. Replies were automatically recorded in a unique excel table, making the 
survey anonymous and efficient, since no question could be skipped. Data processing was performed using the SPSS statistical data analysis tool (IBM Corp 2017, 25.0. Armonk, New York). Descriptive statistics were used for a detailed analysis of phenomena. The chi-squared test in this investigation was used to determine whether there was a significant difference between the expected frequencies and the observed frequencies, where it was assumed that the null hypothesis was true.

\section{RESULTS AND DISCUSSION}

\section{Profile of honey consumers}

Respondents from Serbia consisted of both men and women, with women being more represented $(60.4 \%)$. In Italy, the sample of respondents also consisted of men and women, with women being more represented (59\%). In Romania, the sample was made up predominantly of women, with even $67.8 \%$ (Table 1 ).

In terms of age, respondents from Serbia consisted mostly of the population aged 20 -40 years. Population under the age of 20 represented the minimum $1.7 \%$, while the population over 50 years of age represented only $8.1 \%$, which should be taken into account when defining the age profile of buyers. The research sample in Italy consisted mostly of the population aged 31 -50 years $(59.2 \%)$.

Table 1

Profile of honey consumers in Italy, Romania and Serbia

\begin{tabular}{|c|c|c|c|c|c|c|c|}
\hline \multicolumn{2}{|c|}{ Profile of respondents who are honey consumers } & \multicolumn{2}{|c|}{ Italy } & \multicolumn{2}{|c|}{ Romania } & \multicolumn{2}{|c|}{ Serbia } \\
\hline & & $\mathrm{Fr}^{*}$ & $\%$ & $\mathrm{Fr}^{*}$ & $\%$ & $\mathrm{Fr}^{*}$ & $\%$ \\
\hline \multirow{2}{*}{ Gender } & Female & 360 & 59.0 & 375 & 67.8 & 285 & 60.4 \\
\hline & Male & 250 & 41.0 & 178 & 32.2 & 187 & 39.6 \\
\hline \multirow{6}{*}{ Age } & $<20$ & & & 54 & 9.8 & 8 & 1.7 \\
\hline & $>60$ & 44 & 7.2 & 8 & 1.4 & 23 & 4.9 \\
\hline & $20-30$ & 104 & 17.0 & 361 & 65.3 & 160 & 33.9 \\
\hline & $31-40$ & 187 & 30.7 & 81 & 14.6 & 160 & 33.9 \\
\hline & $41-50$ & 174 & 28.5 & 33 & 6.0 & 82 & 17.4 \\
\hline & $51-60$ & 101 & 16.6 & 16 & 2.9 & 39 & 8.3 \\
\hline \multirow{5}{*}{$\begin{array}{l}\text { Level of } \\
\text { education }\end{array}$} & Elementary school & 2 & 0.3 & 20 & 3.6 & 3 & 0.6 \\
\hline & Graduation & 234 & 38.4 & 234 & 42.3 & 141 & 29.9 \\
\hline & High school & 176 & 28.9 & 202 & 36.5 & 41 & 8.7 \\
\hline & Middle school & 18 & 3.0 & 1 & 0.2 & 105 & 22.2 \\
\hline & Other (MA, PhD) & 180 & 29.5 & 96 & 17.4 & 182 & 38.6 \\
\hline \multirow{8}{*}{$\begin{array}{l}\text { Total } \\
\text { average } \\
\text { income (per } \\
\text { month) of } \\
\text { your } \\
\text { household }\end{array}$} & $<500$ euros & & & 192 & 34.7 & 55 & 11.7 \\
\hline & $501-1000$ euros & 29 & 4.8 & 144 & 26.0 & 186 & 39.4 \\
\hline & $1001-2000$ euros & 191 & 31.3 & 74 & 13.4 & 172 & 36.4 \\
\hline & $2001-4000$ euros & 237 & 38.9 & 24 & 4.3 & & \\
\hline & $4001-6000$ euros & 61 & 10.0 & 5 & 0.9 & & \\
\hline & Over 6000 euros & 30 & 4.9 & 3 & 0.5 & & \\
\hline & I don't know & 62 & 10.2 & & & 44 & 9.3 \\
\hline & No answer & & & 111 & 20.1 & 15 & 3.2 \\
\hline \multirow{7}{*}{$\begin{array}{l}\text { Number of } \\
\text { household } \\
\text { members }\end{array}$} & 1 & 97 & 15.9 & 34 & 6.1 & 38 & 8.1 \\
\hline & 2 & 166 & 27.2 & 91 & 16.5 & 100 & 21.2 \\
\hline & 3 & 141 & 23.1 & 153 & 27.7 & 125 & 26.5 \\
\hline & 4 & 167 & 27.4 & 209 & 37.8 & 154 & 32.6 \\
\hline & 5 & 29 & 4.8 & 39 & 7.1 & 42 & 8.9 \\
\hline & More than 5 & 9 & 1.5 & 27 & 4.9 & 13 & 2.8 \\
\hline & No answer & 1 & 0.2 & & & & \\
\hline \multirow{4}{*}{$\begin{array}{l}\text { Do you } \\
\text { have } \\
\text { children or } \\
\text { parents who } \\
\text { live with you } \\
\text { in the } \\
\text { household? }\end{array}$} & $\begin{array}{l}\text { I have children and parents living in } \\
\text { household }\end{array}$ & 12 & 2.0 & 65 & 11.8 & 38 & 8.1 \\
\hline & I have children living in household & 249 & 40.8 & 79 & 14.3 & 100 & 21.2 \\
\hline & $\begin{array}{l}\text { I have no children and parents at } \\
\text { home }\end{array}$ & 246 & 40.3 & 153 & 27.7 & 125 & 26.5 \\
\hline & I have parents living in household & 103 & 16.9 & 256 & 46.3 & 154 & 32.6 \\
\hline
\end{tabular}


Population under the age of 20 was not represented, while the other two age groups 50-59 and 20-29 were represented with $33.6 \%$, which should be taken into account when defining the age profile of buyers. In Romania, the most represented group was between 20-40 years of age (80\%).

High participation of younger age groups of respondents, a group under the age of 20 and a group aged 20-29, indicated high awareness and level of education about the importance of consuming honey, and regarding the fact that 3-4 member families are predominant, it means that the family members adopt healthy lifestyle and take over their parents' habits.

The research sample was dominated by gra-duated and high school population, but there was also a relevant number of respondents with other education (MA, PhD), which is also important for defining the customer profile.

Considering that in the research sample the respondents with higher education were predominant, it is not surprising that the average household income was higher than the average income in Serbia, Romania and Italy. In Italy, most of the consumers have income from 2001-4000 euros. The income of most Romanian consumers was either less than 500 euros or from 501-1000 euros, which is very similar to the structure in Serbia.

In the research sample conducted in Serbia, two-member, three-member and fourmember households were equally represented. In the research sample from Italy, two-member, three-member and fourmember households were equally represented, while there was also a significant share of one-member families. In Romania, three-member households and fourmember household werre the most represented $(65.5 \%)$, while two-member households participated with $16.5 \%$ in the sample and the share of families with 5 and more than 5 members was significant $(12 \%)$.

The majority of the surveyed population in Serbia consisted of either those living with children $(37 \%)$ or those living with parents in a household (32\%). In Italy, there was a high participation of families that were without children and parents. This indicates that the reason for consumption of honey is not caring for the health of a family member, but primarily as a result of care for one's own health. Still, $58 \%$ of families have children or live with their parents, so the other motive was also present. In Romania, as many as $46.3 \%$ of the respondents live in the same household with their parents, so we think that their elderly family members take care of their health, or they buy honey as a result of caring for a family member.

Also, significant percentages $(27.7 \%)$ were households without children and parents and those respondents take care of their own health.

\section{Trends and habits in honey consumption}

From the obtained results, we noted that of the total number of honey-consuming respondents in Serbia, $30.5 \%$ of them buy honey once a month, $42.8 \%$ once in 3 months, while $27.1 \%$ of the respondents buy it only once in a half year period, which means that their consumption of honey is quite small. In Italy, $35.2 \%$ of the respondents buy honey once a month, then $31.3 \%$ once every three months and $33.4 \%$ once every six months (Table 2 ). We noted that there was a very uniform structure of users in all three categories. In Romania, $37.8 \%$ buy it once a month, $45 \%$ once in three months and $17.2 \%$ once in a six month period. We noted that the most important category included respondents who buy honey monthly and quarterly.

The results of the research pointed to the fact that the strongest tendency of consumers from Serbia was to purchase a package of $1 \mathrm{~kg}$ (56.1\% of the respondents). $32 \%$ of the respondents buy a $500-$ g pack, while only $11.9 \%$ of the respondents buy a $250-g$ package. The results of the research indicated that the highest preference of consumers in Italy is towards purchasing 250-g packages $(42.8 \%)$. Around $21 \%$ of the respondents buy $1-\mathrm{kg}$ package, while $36.4 \%$ of the respondents buy a 500-g package. In Romania we obtained the following structure. 
Table 2

Questions related to trends and habits in honey consumption in Italy, Romania and Serbia

\begin{tabular}{|c|c|c|c|c|c|c|c|}
\hline \multirow{2}{*}{\multicolumn{2}{|c|}{$\begin{array}{l}\text { Questions related to trends and habits in honey } \\
\text { consumption }\end{array}$}} & \multicolumn{2}{|c|}{ Italy } & \multicolumn{2}{|c|}{ Romania } & \multicolumn{2}{|c|}{ Serbia } \\
\hline & & $\mathrm{Fr}^{*}$ & $\%$ & $\mathrm{Fr}^{*}$ & $\%$ & Fr* & $\%$ \\
\hline \multirow{3}{*}{$\begin{array}{l}\text { How often do } \\
\text { you buy } \\
\text { honey? }\end{array}$} & At least once a month & 215 & 35.2 & 209 & 37.8 & 144 & 30.5 \\
\hline & Once in 3 months & 191 & 31.3 & 249 & 45 & 202 & 42.8 \\
\hline & Once in 6 months & 204 & 33.4 & 95 & 17.2 & 126 & 27.1 \\
\hline \multirow{3}{*}{$\begin{array}{l}\text { What package } \\
\text { size of honey } \\
\text { do you buy? }\end{array}$} & $1 \mathrm{~kg}$ & 127 & 20.8 & 228 & 41.2 & 265 & 56.1 \\
\hline & $250 \mathrm{~g}$ & 261 & 42.8 & 111 & 20.1 & 56 & 11.9 \\
\hline & $500 \mathrm{~g}$ & 222 & 36.4 & 214 & 38.7 & 151 & 32 \\
\hline \multirow{3}{*}{$\begin{array}{l}\text { What price do } \\
\text { you pay for } 1 \\
\mathrm{~kg} \text { of honey? }\end{array}$} & 5 euros & 66 & 10.8 & 124 & 22.4 & 169 & 35.8 \\
\hline & $5-10$ euros & 428 & 70.2 & 385 & 69.6 & 244 & 51.7 \\
\hline & More than 10 euros & 116 & 19.1 & 44 & 7.9 & 59 & 12.5 \\
\hline \multirow{6}{*}{$\begin{array}{l}\text { Where do you } \\
\text { often buy } \\
\text { honey? }\end{array}$} & Directly from the manufacturer & 278 & 45.6 & 440 & 79.6 & 209 & 44.3 \\
\hline & Local markets & 62 & 10.2 & 4 & 0.7 & 75 & 15.9 \\
\hline & At marketplace & & 0.0 & & & 168 & 35.6 \\
\hline & Food/honey festivals & 45 & 7.4 & 58 & 10.5 & 13 & 2.8 \\
\hline & In supermarkets and hypermarkets & 211 & 34.6 & 43 & 7.8 & & 0.0 \\
\hline & Others & 14 & 2.3 & 8 & 1.4 & 7 & 1.5 \\
\hline \multirow{8}{*}{$\begin{array}{l}\text { What kind of } \\
\text { honey do you } \\
\text { buy? }\end{array}$} & Linden honey & 123 & & 107 & & 149 & \\
\hline & Acacia honey & 370 & & 353 & & 315 & \\
\hline & Flower honey & 362 & & 405 & & 275 & \\
\hline & Sunflower honey & 18 & & 26 & & 21 & \\
\hline & Chestnut honey & 194 & & 0 & & & \\
\hline & Citrus honey & 84 & & 0 & & & \\
\hline & Forest honey & 5 & & 54 & & 89 & \\
\hline & Other types of honey & 67 & & 44 & & 19 & \\
\hline
\end{tabular}

${ }^{\star}$ Frequency

ture in the purchase of honey: $1-\mathrm{kg}$ packing $-41.2 \%$ of the respondents; $38.7 \%$ of the respondents buy a $500-g$ packing, while only $20.1 \%$ of the respondents buy a $250-g$ packing. The largest number of respondents in Serbia $(51.7 \%)$ pays between 5-10 euros per $\mathrm{kg}$ of honey.

The large percentage of the respondents $(35.8 \%)$, pays less than 5 euros per $\mathrm{kg}$ of honey. In Italy, $70.2 \%$ of respondents pay between 5-10 euros for one $\mathrm{kg}$ of honey. In Romania, the structure is similar in the category 5-10 euros (even 69.6\%), while there is a much higher percentage of those who pay honey less than 5 euros (22.4\%).

By summing up the responses of the respondents from Serbia to the question of where they buy honey, we conclude that the purchase from producers is predominant $(44.3 \%)$ and on market places $(35.6 \%)$. In Italy, $45.6 \%$ of the respondents buy directly from producers, and even $34.6 \%$ of the respondents buy honey in supermarkets. In Romania, honey is predominantly bought from producers $(79.6 \%$ of respondents), and also at organized ex- hibitions $(10.5 \%)$ by a certain number of respondents.

Linden honey, regarding its consumption, does not belong to the category that has a predominant position on the market. Acacia and meadow honey in comparison to the lime honey are much more represented in the consumption among the surveyed population in all three countries.

\section{Sociologic characteristics of honey consumers}

The majority of respondents use honey because they love and consider it as a healthy food. The consumer structure is similar in all three countries. Motives for honey consumption are, on the one hand, the satisfaction about the taste honey offers $(60 \%)$ in Italy, $57.7 \%$ in Romania and $53.8 \%$ in Serbia. A common opinion is that honey provides medical benefits, so the response structure is: in Italy $31.3 \%$, Romania $36.2 \%$ and Serbia $37.3 \%$ (Table $3)$.

The majority of respondents buy honey throughout the year, while a significant number of them use honey during the winter. The consumer structure in Italy and 
Serbia is very similar; while in Romania $85 \%$ of users buy honey throughout the year which represents the right consumption. It can be concluded that honey is a product that is bought throughout the year in accordance with consumers' taste preferences, as well as with their lifestyle that is reflected in health concerns. The obtained results showed that a purchase decision of an individual is influenced by two main groups - families and friends. While the majority of respondents make the purchase decision on their own, which is most likely associated with the fact that due to the long-term purchase of products from the same producer, they do not need any information in the decision-making process, so they skip the stages of information gathering and evaluating alternatives and make the routine purchase decision.

In Italy, as many as $59 \%$ of the respondents claimed that they have healthy nutrition, $39.7 \%$ said they have a partially healthy nutrition, which, in addition to the high share of those who regularly or occasionally exercise, points to the leading of healthy lifestyle. In Romania, there were more respondents who said that they have partially healthy nutrition and who exercise periodically, which means an opportunity for education and improvement of knowledge about healthy lifestyles. In Serbia, as much as $59 \%$ of respondents think that they have a healthy nutrition, and $56.8 \%$ of them occasionally exercise, while $40.9 \%$ think that they have healthy nutrition and even $30 \%$ regularly exercise.

The obtained results indicated that in all three analyzed countries honey consumers make a purchase decision by themselves. In Romania, the suggestion of family members plays an important role.

The Chi-square test showed that there was a significant difference between genders $\left(X^{2}(2, N=1635)=10.70, p=0.005\right)$; Age difference $\left(X^{2}(12, N=1635)=\right.$ 469.59, $p=0.000)$; Educational difference $\left(X^{2}(8, N=1635)=348.51, p=0.000\right)$; difference in number of family members $\left(X^{2}(12, N=1635)=77.77, p=0.000\right)$; difference related to with whom they live in the household $\left(X^{2}(6, N=1635)=220.79\right.$, $p=0.000)$. There is a statistically signi- ficant difference between the countries in terms of demographic and economic characteristics of consumers (Table 4).

The Chi-square test showed that there was a significant difference in the frequency of the purchase of honey $\left(X^{2}(4, N\right.$ $=1635)=49.61, p=0.000)$; difference according to package size $\left(\mathrm{X}^{2}(10, \mathrm{~N}=\right.$ $1635)=1675.71, p=0.000)$; difference in price per kilogram of honey $\left(\mathrm{X}^{2}(4, \mathrm{~N}=\right.$ $1635)=119.86, p=0.000)$. There was a statistically significant difference between the countries when it comes to trends and preferences in honey consumption.

The Chi-square test showed that there was a significant difference in the opinion whether the respondents have healthy nutrition $\left(X^{2}(4, N=1635)=136.36, p=\right.$ $0.000)$; whether they exercise regularly $\left(X^{2}\right.$ $(4, \mathrm{~N}=1635)=62.139, \mathrm{p}=0.000)$; whether they buy food in organic food shops $\left(X^{2}(6, N=1635)=871.525, p=\right.$ $0.000) ;$ a difference whether they like honey or use it because it is healthy $\left(\mathrm{X}^{2}(6\right.$, $\mathrm{N}=1635)=170.941, \mathrm{p}=0.000) ; \mathrm{a}$ difference according to the time of consumption of honey in terms of the seasons $\left(X^{2}(8, N=1635)=107.082, p=\right.$ $0.000)$. There was a statistically significant difference between the countries when it comes to sociological characteristics of the consumers.

A honey consumption survey should consider the following characteristics: honey consumer characteristics, product price and consumer income, as well as habits in the consumption of honey. When it comes to the characteristics of honey consumers, the research showed that both men and women were represented in a high percentage, which is in line with the results of the research study conducted by Ćirić et al. (2015) for Serbia, while in Malaysia the participation of women was much higher (Yeow et al., 2013).

According to the age structure, in Italy dominated people with 30-49 years of age, in Romania and Serbia, people from 20 to 39 years, which is in line with the results of Pocol (2012), who reported that consumers of honey in Romania are 26-50 years of age. In fact, recent results showed that the age limit of honey 
consumers has shifted towards a younger age, which is certainly a positive tendency. Increased use of honey among younger consumers is related to the increased awareness of the care for their health as well as to the leading of healthy lifestyle, which is in line with the findings of Sanitas Prais and Houthakker (1971), Pocol and Bolboacă (2013), Ćirić et al. (2015) and Arvanitoyannis and Krystallis (2006). The results obtained by the authors in this study harmonizes with the conclusions of Pocol and Balboca (2013), Yeow et al. (2013) and Ćirić et al. (2015) stating that consumers of older age consume honey in a small percentage. The reduced participation of older consumers can be explained by the sensitivity of this group of respondents to the price of the products and lower income in relation to the employed population. Since the total sample is dominated by families in which the respondents live with their parents, then the reduced participation of older customers can be explained by the fact that the purchases are performed on their behalf by their employed children, who are middle-aged persons. Elderly people do not use the Internet and other modern media very much, so they cannot easily follow the results of research on the benefits of honey consumption.

The significance of the size of the family, i.e. whether the respondents live alone or with their children or parents, greatly affects the consumption of honey. The research conducted in this study confirms the theses of Ćirić et al. (2015) that increased concern for the health of the family members generates consumption of honey.

The level of education is the next significant consumption factor. On the one hand, the higher education level is in correlation with the high professional status, as well as the awareness of consumers about the medical and nutritional characteristics of honey.

The results of the study show that honey consumers in all three analyzed countries have a high level of education, which is in agreement with the conclusions of Pocol (2012), Pocol and Balboca (2013), Ismaiel et al. (2014) and Ćirić et al. (2015). Unlike the results obtained by these authors, Yeow et al. (2013) concluded that consumers with higher education consume honey in the high percentage, but their motives are different. The amount of income is a very important consumption factor that can be considered from two aspects - as a budget constraint and as a factor of readiness to pay the premium price for certified quality honey.

Regarding budget constraints, the majority of respondents in Italy have an average household income in the range of 1,000 to 4,000 euros, in Romania up to 1000 euros, and in Serbia, the majority of households have an income in the range of 501-1000 euros (39.4\%) and 1001-2000 euros $(36.4 \%)$. The study found that respondents are sensitive to the price (Murphy et al., 2000), stating that it is an expensive product (Prais and Houthakker, 1971; Pocol, 2012; Pocol and Balboca, 2013; Ismaiel et al., 2014; Haderbache and Mohammed, 2015), especially in the countries where the supply is low and honey is imported. Although honey has medical properties (Roman et al., 2013; Ismaiel et al., 2014), such as positive effects on immunity and general health (Pocol and Balboca, 2013; Yeow et al., 2013), very small number of respondents are willing to pay higher price for quality honey (Cosmina et al., 2016). In this situation, consumers develop loyalty relationship (Yeow et al., 2013) with domestic producers, thereby avoiding paying a higher price for honey with a certificate, which is confirmed also in this research. The research results indicate the tendency of consumers to buy from a known producer, which is in accordance with Pocol and Balboca (2013), Roman et al. (2013) and Cosmina et al. (2016). The survey confirmed the readiness of consumers to buy honey in both supermarkets and health food shops. Studies confirm that the most important factors for consumers are: quality of honey, color, taste, smell and texture (Ismaiel et al., 2014; Roman et al., 2013; Haderbache and Mohammed, 2015; Murphy et al., 2000), while only the small number of consumers prefers attractive packing Cosmina et al., 2016; Arvanitoyannis and Krystallis, 2006). 
Table 3

Questions related to sociologic characteristics of honey consumers in Italy, Romania and Serbia

\begin{tabular}{|c|c|c|c|c|c|c|c|}
\hline \multirow{2}{*}{\multicolumn{2}{|c|}{$\begin{array}{l}\text { Questions related to sociologic characteristics of } \\
\text { honey consumers }\end{array}$}} & \multicolumn{2}{|c|}{ Italy } & \multicolumn{2}{|c|}{ Romania } & \multicolumn{2}{|c|}{ Serbia } \\
\hline & & \multirow{2}{*}{$\begin{array}{c}\mathrm{Fr}^{*} \\
8\end{array}$} & \multirow{2}{*}{$\%$} & \multirow{2}{*}{\begin{tabular}{c|}
$\mathrm{Fr}^{*}$ \\
40
\end{tabular}} & \multirow{2}{*}{\begin{tabular}{c|}
$\%$ \\
7.2
\end{tabular}} & \multirow{2}{*}{\begin{tabular}{c|}
$\mathbf{F r}^{*}$ \\
28
\end{tabular}} & \multirow{2}{*}{$\begin{array}{c}\% \\
5.9\end{array}$} \\
\hline Do you think you & No & & & & & & \\
\hline have healthy & Partially & 242 & 39.7 & 360 & 65.1 & 279 & 59.1 \\
\hline nutrition? & Yes & 360 & 59.0 & 153 & 27.7 & 193 & 40.9 \\
\hline \multirow{3}{*}{$\begin{array}{l}\text { Do you exercise or } \\
\text { engage in some } \\
\text { physical activity? }\end{array}$} & No & 98 & 16.1 & 65 & 11.8 & 90 & 19.1 \\
\hline & Occasionally & 257 & 42.1 & 342 & 61.8 & 268 & 56.8 \\
\hline & Regularly & 255 & 41.8 & 146 & 26.4 & 142 & 30.1 \\
\hline \multirow{3}{*}{$\begin{array}{l}\text { Do you buy any } \\
\text { products in organic } \\
\text { food shops? }\end{array}$} & No & 242 & 39.7 & 170 & 30.7 & 65 & 13.8 \\
\hline & Sometimes & 185 & 30.3 & 293 & 53.0 & 128 & 27.1 \\
\hline & Yes & 183 & 30.0 & 90 & 16.3 & 307 & 65.0 \\
\hline \multirow{3}{*}{$\begin{array}{l}\text { Do you consume } \\
\text { honey every day } \\
\text { because you like it or } \\
\text { because it is } \\
\text { healthy? }\end{array}$} & I consume it because I like it & 366 & 60.0 & 319 & 57.7 & 254 & 53.8 \\
\hline & $\begin{array}{l}\text { I consume it because it is } \\
\text { healthy }\end{array}$ & 191 & 31.3 & 200 & 36.2 & 176 & 37.3 \\
\hline & $\begin{array}{l}\text { I do not like it very much, I only } \\
\text { consume it when I am ill }\end{array}$ & 53 & 8.7 & 34 & 6.1 & 70 & 14.8 \\
\hline \multirow{4}{*}{$\begin{array}{l}\text { Do you consume } \\
\text { honey throughout the } \\
\text { year or you increase } \\
\text { consumption during } \\
\text { a specific time of the } \\
\text { year (or season)? }\end{array}$} & Mostly in autumn & 12 & 2.0 & 5 & 0.9 & 8 & 1.7 \\
\hline & Mostly in spring & 1 & 0.2 & 5 & 0.9 & 6 & 1.3 \\
\hline & Mostly in winter & 209 & 34.3 & 74 & 13.4 & 129 & 27.3 \\
\hline & Throughout the year & 388 & 63.6 & 469 & 84.8 & 329 & 69.7 \\
\hline \multirow{6}{*}{$\begin{array}{l}\text { Do other people's } \\
\text { opinions affect your } \\
\text { decision to buy } \\
\text { honey? }\end{array}$} & I make my own decision & 520 & & 385 & & 291 & \\
\hline & Family & 75 & & 156 & & 161 & \\
\hline & Doctors & 15 & & 15 & & 37 & \\
\hline & Media & 35 & & 7 & & 21 & \\
\hline & Friends & 21 & & 29 & & 91 & \\
\hline & Other & 5 & & 1 & & 18 & \\
\hline
\end{tabular}

${ }^{\text {*Frequency }}$

Table 4

Results of chi-squared test

\begin{tabular}{lcccc} 
Variable & $\begin{array}{c}\text { Pearson } \mathbf{x}^{2} \\
\text { value }\end{array}$ & df & $\begin{array}{c}\text { Asymp. } \\
\text { Sig. } \\
\text { (2-sided) }\end{array}$ & $\begin{array}{c}\text { Likelihood } \\
\text { Ratio }\end{array}$ \\
\hline Gender & $10.698^{\mathrm{a}}$ & 2 & 0.005 & 10.812 \\
Age & $469.590^{\mathrm{a}}$ & 12 & 0.000 & 497.894 \\
Level of education & $348.511^{\mathrm{a}}$ & 8 & 0.000 & 358.172 \\
Number of household members & $77.771^{\mathrm{a}}$ & 12 & 0.000 & 77.541 \\
Do you have children or parents who live with you in the & $220.789^{\mathrm{a}}$ & 6 & 0.000 & 236.291 \\
household? & $49.605^{\mathrm{a}}$ & 4 & 0.000 & 51.330 \\
How often do you buy honey? & $1675.712^{\mathrm{a}}$ & 10 & 0.000 & 2185.850 \\
What package size of honey do you buy? & $119.858^{\mathrm{a}}$ & 4 & 0.000 & 122.401 \\
What price do you pay for 1 kg of honey? & $136.355^{\mathrm{a}}$ & 4 & 0.000 & 140.046 \\
Do you think your nutrition is healthy? & $62.139^{\mathrm{a}}$ & 4 & 0.000 & 62.019 \\
Do you exercise or engage in some physical activity? & $871.525^{\mathrm{a}}$ & 6 & 0.000 & 977.520 \\
Do you buy any products in organic food shops? & $170.941^{\mathrm{a}}$ & 6 & 0.000 & 197.309 \\
$\begin{array}{l}\text { Do you consume honey every day because you like it or } \\
\text { because it is healthy? }\end{array}$ & & & & \\
Do you consume honey throughout the year or you & & & & \\
increase consumption during a specific time of the year & $107.082^{\mathrm{a}}$ & 8 & 0.000 & 112.927 \\
(or season)? & & & & \\
\hline
\end{tabular}

\section{CONCLUSIONS}

The results of the study showed that in terms of demographic and economic characteristics there is a statistically signifycant difference between the respondents- consumers of honey in Italy, Romania and Serbia. Consumers of honey in the three analyzed countries have different consumption habits, i.e. the consumption trends are different, as well as the sociological characteristics of consumers. 
Based on the results of the research, a typical profile of honey consumers has been created. In Italy, honey consumers are 3049 years of age, highly educated, with an average income of 1000-4000 euros. In the survey, the emphasis was not on the existence of a difference among customers, i.e. the people who buy honey and the consumers who use the honey. It is actually for the reason of taking care of family members that the participation of women as honey consumers is more significant. Consumers prefer smaller packages of honey and specific flavors such as eucalyptus, chestnut, citrus, along with traditional floral and acacia honey. They are used to buying honey from producers, with a developed habit of buying honey in supermarkets as well. In Romania, honey consumers are aged 20 - 30 years, highly educated with income up to 1000 euros per month. Women, in this sample as well, are the most important for the purchase of honey. When it comes to preferences and shopping habits, Romanian consumers are traditional and buy bigger packing, directly from the producers, mostly acacia and floral honey. Consumers in Serbia are more women, aged 20-39 years, highly educated with the average income of 5002000 euros. Consumers have built a relationship of loyalty with certain producers and buy large packing of honey throughout the year, mostly floral, acacia and linden honey.

Therefore, this research showed that the educational level, the amount of income and the size of the family, i.e. whether the consumers live in the household with children and parents, represent the main characteristics of consumers, which influence their behavior. Among the respondents in Italy, Romania and Serbia, the consumption of honey is increasing with the increase of these parameters. Considering that respondents in all three countries state that they spend $5-10$ euros per $\mathrm{kg}$ in average, we conclude that there is no correlation between the key characterristics of honey consumers and the price they pay for honey. The results of the research show that non-price factors of demand are of higher importance. This conclusion is in accordance with the statements of the respondents that they have healthy nutrition and exercise, i.e. the lifestyle determines honey consumption. Primary motives for buying honey are the taste of honey and the awareness that it is healthy and quality food. Buyers who buy honey throughout the year are predominant, but those buyers who buy honey in winter for health reasons are also statistically significant.

The results of the study have shown that there is a similarity between the respondents who use honey and those who do not, which led us to the conclusion that demographic and economic characteristics do not affect decisions related to the consumption of honey. The main reasons why honey is not bought are the lack of habit or health contraindications.

Finally, to increase the consumption of honey among the respondents of all levels of education, income and age, it will be necessary to find the way to attract these consumers or to identify their preferences. The results of previous studies showed that honey is a source of easily-digestible simple sugars, proteins, acids, amino acids, minerals and a number of other elements, such as pigments, phenolic compounds, colloids, sugar alcohol and vitamins. Nowadays, honey products are being developed as nutritional health supplements, since honey has beneficial effects on human health.

On the other hand, its consumption is individually determined and consumers make purchase decisions on their own needs. For this reason, consumer education will be necessary, and in this process, the media and medical workers will have to change their current role. This means, they will have to promote a healthy lifestyle and nutrition and be the advocates of the adoption of heal-thy eating habits.

\section{ACKNOWLEDGEMENTS}

This paper is a part of the project (114451-821/2015-02) „Improving the Competitiveness of Fruškogorski Linden Honey on the Domestic and International Market in the Function of Sustainable Development of AP Vojvodina" which is financed by Provincial Secretariat for Science and Technological Development of AP Vojvodina. The authors would like to express sincere 
gratitude to the researchers who contributed to this paper, professor Cristina Pocol and professor Daniele Cavicchioli.

\section{REFERENCES}

1. Arvanitoyannis, I., Krystallis, A. (2006). An empirical examination of the determinants of honey consumption in Romania. International Journal of Food Science and Technology, 41, 1164-1176.

2. Bogoeva, I. (2018). Production of safety food by phytoremediation methods. Journal of Agronomy, Technology and Engineering Management, 1(1), 39-44.

3. Ćirić, M., Ignjatijević, S., Cvijanović, D. (2015). Research of honey consumers' behavior in province of Vojvodina. Economics of Agriculture, 62 (3), 627-644.

4. Cosmina, M., Gallenti, G., Marangon, F., Troiano, S. (2016). Attitudes towards honey among Italian consumers: A choice experiment approach. Appetite, 99, 52-58.

5. Haderbache, L., Mohammedi, A. (2015). Etude sur le comportement de consommation du miel en Algérie: attentes et préférences Honey consumption behaviors in Algeria: survey and expectations. Revue Agriculture, 9, 19-24.

6. Ignjatijević, S., Ćirić, M., Čavlin, M. (2015). Analysis of honey production in Serbia aimed at improving the international competitiveness. Custos e Agronegocio Online, 11 (2), 194-213.

7. Ismaiel, S., Al Kahtani, S., Adgaba, N., AlGhamdi, A.A., Zulail, A. (2014). Factors that affect consumption patterns and market demands for honey in the Kingdom of Saudi Arabia. Food and Nutrition Sciences, 5, 17251737.

8. Jakšić, S., Mihaljev, Ž., Kartalović, B., Babić, J., Vidaković, S., Živkov Baloš, M. (2018). Evaluation of Elisa tests as screening methods for determination of antibiotics and sulfonamides in honey. Food and Feed Research, 45 (1), 11-18.

9. Magnusson, M.K., Avrola, A., Hursti Koivisto, U. K., Aberg, L., Sjoden, P.O. (2001). Attitudes to- wards organic foods among Swedish consumers. British Food Journal, 103 (3), 209-226.

10. Murphy, M., Cowan, C., Henchion, M., O'Reilly, S. (2000). Irish consumer preferences for honey: a conjoint approach. British Food Journal, 102 (8), 585-598.

11. Plavaša, N., Stojanović, D., Stojanov, I., Puvača, N., Stanaćev, V., Đuričić, B. (2011). Evaluation of oxytetracycline in the prevention of American foulbrood in bee colonies. African Journal of Agricultural Research, 6 (6), 16211626.

12. Pocol, C.B. (2012). Consumer preferences for different honey varieties in the North West Region of Romania. Lucrari Stiintifice serie Agronomie, 55 (2), 263-266.

13. Pocol, C.B., Bolboacă, S.D. (2013). Perceptions and trends related to the consumption of honey: A case study of North-West Romania. International Journal of Consumer Studies, 37 (6), 642-649.

14. Prais, S.J., Houthakker, H.S. (1971). The Analysis of Family Budgets, Vol. 2. Cambridge, University Press Cambridge.

15. Roman, A., Popiela-Pleban, E., Kozak, M. (2013). Factors influencing consumer behavior relating to the purchasing of honey part 1 . The buying process and the level of consumption. Journal of Apicultural Science, 57 (2), 159-172.

16. Stolzenbach, S., Wender, L.P.B., Derek V.B. (2013). Consumer concepts in new product development of local foods: Traditional versus novel honeys. Food Research International, 52, 144-152.

17. Volatier, J.L. (2000). Enquête Individuelle et Nationale sur les Consommations Alimentaires (INCA). Agence française de sécurité sanitaire des aliments (Afssa), Tec\&Doc Lavoisier, Paris, France. [National and Individual Survey on Eating Consumptions, French Agency for Food Security (Afssa), Tec \& Doc Lavoisier, Paris, France].

18. Yeow, S.H.C., Chin, S.T.S., Yeow, J.A., Tan, K.S. (2013). Consumer purchase intentions and honey related products. Journal of Marketing Research and Case Studies, 1, 1-15. 


\section{КОМПАРАТИВНА АНАЛИЗА ПОТРОШЊЕ МЕДА У РУМУНИЈИ, ИТАЛИЈИ И СРБИЈИ}

Светлана Д. Игњатијевић ${ }^{1}$, Радивој В. Продановић ${ }^{2}$, Јелена 3. Бошковић ${ }^{2}$, Никола М. Пувача ${ }^{2}$, Мирела J. Томаш Симин ${ }^{3}$, Татјана А. Пеулић ${ }^{4}$, Оливера М. Ђурагић ${ }^{4}$

${ }^{1}$ Универзитет Привредна академија, Факултет за економију и инжењерски менаџмент, Департман за економију, 21000 Нови Сад, Цвећарска бр. 2, Србија

${ }^{2}$ Универзитет Привредна академија, Факултет за економију и инжењерски менаџмент, Департман за инжењерски менаџмент у агробизнису, 21000 Нови Сад, Цвећарска бр. 2, Србија

${ }^{3}$ Универзитет у Новом Саду, Пољопривредни факултет, Департман за агроекономију и социологију села, 21000 Нови Сад, Трг Доситеја Обрадовића бр. 8, Србија

${ }^{4}$ Универзитет у Новом Саду, Научни институт за прехрамбене технологије у Новом Саду, 21000 Нови Сад, Булевар цара Лазара бр. 1, Србија

Сажетак: На потрошњу меда утичу фрактори здравствене користи, као што су карактеристике производа, или демографске и социолошке карактеристике. Циљ истраживања је да се идентификују фактори који утичу на обим потрошње меда, куповне намере потрошача, као и да се дефинише профил потрошача у Румунији, Италији и Србији. Истраживање је спроведено у периоду од 2014. до 2016. године путем упитника. Истражена је статистичка значајност разлике у потрошњи меда у Србији (АП Војводина), Италији (провинција Ломбардија, која географски подсећа на Војводину) и Румунији. За одабир репрезентативног узорка коришћен је метод случајног одабира, а добијени подаци обрађени су помоћу СПСС програма. Најјачи мотиви за конзумацију меда су задовољство које пружа укус меда и перцепција да је то здрава храна. Хи-квадрат тест показује да постоји значајна разлика између земаља у смислу демографских и економских карактеристика потрошача, трендова и тенденција у потрошњи меда и социолошких карактеристика потрошача.

Кључне речи: потрошња меда, профил потрошача, здравствени аспект

Received: 3 March 2019

Received in revised form: 11 April 2019

Accepted: 17 April 2019 